\title{
MATERIAL RESOURCE USE EFFICIENCY IN THE METALLURGICAL INDUSTRY IN THE CONTEXT OF INDUSTRY 4.0
}

\author{
Dominika HRUBÁ, Andrea SAMOLEJOVÁ, Martin LAMPA \\ VSB - Technical University of Ostrava, Faculty of Materials and Technology, Ostrava, Czech Republic, EU, \\ dominika.kostelova.st@vsb.cz, andrea.samolejova@vsb.cz, martin.lampa@vsb.cz
}

https://doi.org/10.37904/metal.2021.4273

\begin{abstract}
Maintaining competitiveness is becoming increasingly difficult, not only for industrial companies in an open economy. Especially in times of extended crisis, only those who respond most quickly to change will succeed. The implementation of tools for Industry 4.0 can reduce an employer's dependence on human resources and thereby increase the flexibility of the company in responding to the needs of their customers. Experience with the use of Industry 4.0 technology has proved greater efficiency in material flows and therefore the use of available resources in all branches of industry.

Industry 4.0 will create the conditions for the emergence of new business models and production processes. As a result, it will be possible to achieve a new level of mass production taking into account the individual wishes of customers. It will reduce the energy and raw material intensity of production, enable the maximum use of residual materials as input components into the subsequent production process and increase the efficiency of the use of non-recycled waste within the company.

The paper presents selected elements of Industry 4.0 which could improve the efficiency of resource use in the metallurgical industry in the future. The aim of the article is to define recommendations based on not only positive but also negative experiences which can assist other companies in managing their material flows more efficiently as a result of application of the Industry 4.0 tools.
\end{abstract}

Keywords: Metallurgy, Industry 4.0, efficiency

\section{INTRODUCTION}

The production and processing of iron and steel is historically one of the most intensive operations in terms of input material consumption, energy use and human labor costs. An increase in the proportion of automation in the smelter will lead to products with higher utility value and better sales. However, in such an energyintensive sector as metallurgy, it is understandable that certain limits exist. Through research in the literature, the paper summarizes the effect that the introduction of Industry 4.0 will have on the efficiency of use of material resources in metallurgical companies.

\section{INDUSTRY 4.0}

Industry 4.0 can be characterized as the next stage of development (it is directly referred to as a revolution) in the digitalization of the manufacturing sector, which is subject to several factors: increasing computing power and improved possibilities in interconnecting machines and objects (Internet of Things), but also within individual services (Internet of Services) and people (Internet of People). An increase in generated and processable data (Big Data) through the use of various sensors is the result, including better mappable humanhuman, human-machine or machine-machine communication. It is the communication between machines and machines with people (physical and virtual world) resulting from the many innovations and developments in 
the field of Artificial Intelligence (Al). These technological transformations are then reflected in the advent of autonomous robots, advanced computer simulations and virtualization, decentralized control from cloud storage, additive production using 3D printers and augmented reality [1].

The Industry 4.0 concept is very technologically demanding. It requires the quick and accurate acquisition of large amounts of information and subsequent processing and storage in secure repositories. The basic assumptions include CPS (Cyber-Physical Systems), Internet of Things (IOT), Sensors, Data Mining and Big Data, Artificial Intelligence for Systems Management, and Systems Security [2].

Visual concept of Industry 4.0 is in Figure 1. Figure display inputs (raw material, energy and information) and outputs (products, waste.). With the simultaneous action of CPS, IoT, 3D Print, Big Data and clouds. At the upper part of the figure are listed acquired capabilities or benefits such as:

- $\quad$ efficiency,

- flexibility,

- $\quad$ agility,

- modularity,

- customization,

- real-time data, integration,

- prediction,

- $\quad$ simulation, tracking,

- $\quad$ self- control,

- $\quad$ intelligent learning.

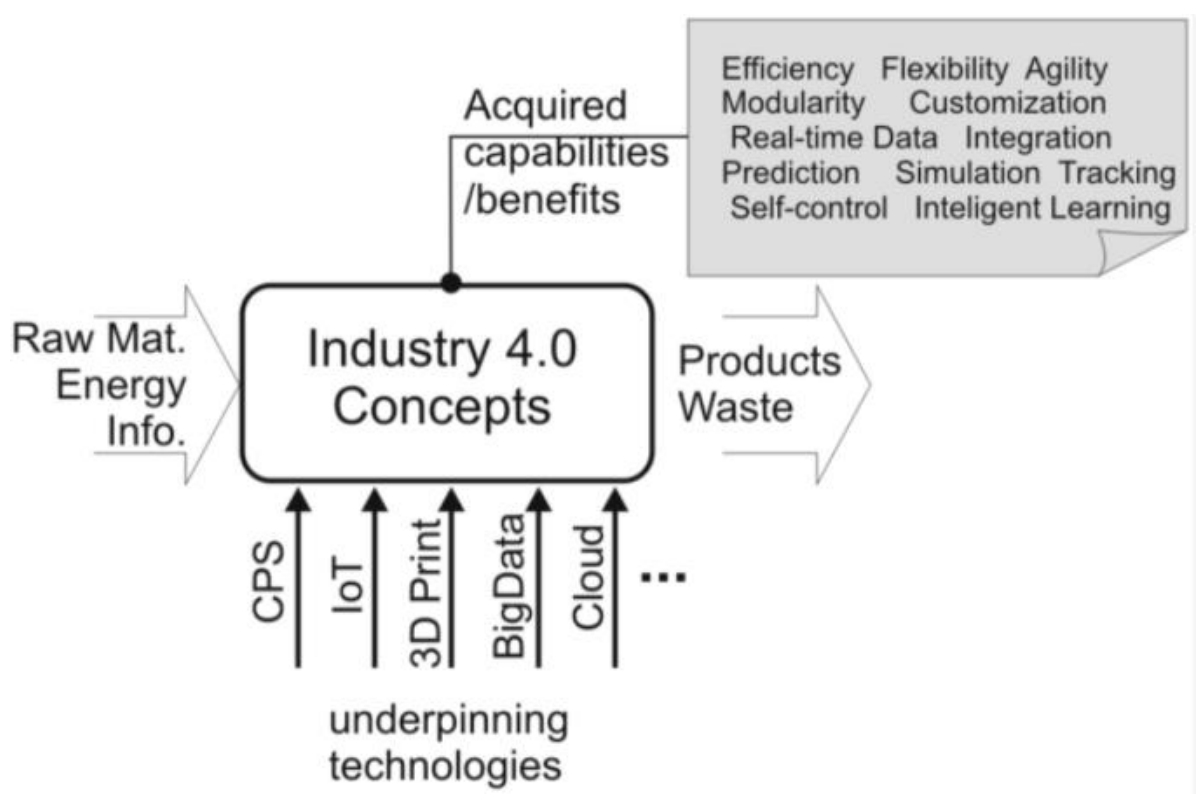

Figure 1 Industry 4.0 concepts

\section{MATERIAL DEMANDS IN METALLURGY}

The economy is exceptionally demanding with respect to material resources. Although domestic material consumption (DMC) has fallen by $13.9 \%$ since 2000 and halved since 1990, it reached 155 million tonnes in 2013. In per unit of GDP terms, this means that in $2013,39 \mathrm{~kg}$ of material was consumed per CZK 1,000 of 
GDP, one third of the level of the early 1990s. The composition of material resources has not changed substantially since 1990, with construction raw materials and coal mining being the main contributors.

Industrial minerals, ores and products made from them account for less than $10 \%$ of total DMC. Given that the total volume of matter in DMC continues to decrease significantly, the stable representation of individual components means that the consumption of coal, ores and construction materials is decreasing. One special material/energy resource is water, mainly because there is little water retention in the landscape, while drawing surface water accounts for more than $40 \%$ of the total volume used in the energy sector, and another fifth in industry and raw material extraction [3].

\section{IMPACT OF INDUSTRY 4.0 ON THE METALLURGICAL INDUSTRY}

With its new automation possibilities, Industry 4.0 promises indisputable benefits to manufacturers of smelters and rolling mills. These usually large, complex and technologically demanding devices include the entire portfolio of energy supply, electrical engineering and automation technology. Most tailor-made solutions usually involve individually tuned processes with appropriate automation solutions [4].

In the field of metallurgical production, a good foundation has been laid for the expansion and further construction of cyber-physical systems. This opinion can be supported by several considerations. Most technologies in the metallurgical industry (from the production of pig iron, steel, foundry technologies and other technologies to support systems such as heating furnaces and the like) are equipped with control systems which meet one component of cyber-physical systems, namely feedback [2].

For most manufacturing companies, a standard reactive approach to equipment maintenance means downtime in the event of failure and the associated financial loss caused by production outages and repairs. Companies are therefore increasingly switching to preventive maintenance under Industry 4.0, which, although slightly more time-consuming at the beginning, clearly guarantees a lower incidence of breakdowns. However, one of the disadvantages of a preventive maintenance plan may be that preventive interventions generate expenses which can often be unnecessary, and as a result, may not guarantee the efficiency of the process. Often, components are inspected or replaced significantly earlier than their actual service life-for assuranceto prevent them from failing during production. However, the risk arises that if equipment is used improperly or is inadvertently overloaded, some components may wear out more quickly than originally planned [5].

It cannot be assumed that the average consumer will be interested in whether the product they have selected has been manufactured with a minimum of energy consumption since their decision will likely be based on the final selling price. Clearly though, a reduction in the energy intensity of production is very likely to be reflected in a lower product selling price (or in the producer's ability to manipulate margins), therefore providing an undoubtable competitive advantage [6].

\section{DIRECTIONS OF FURTHER DEVELOPMENT}

The COVID-19 crisis may accelerate the digital transformation of Czech companies. More than half of the survey participants conceded that they will invest more in Industry 4.0 technologies because of the experience they gained from the crisis. It is good that companies are also aware of the benefits of the Industry 4.0 concept from the perspective of increased resilience to crisis and recession. At specific companies, the crisis has also accelerated the use of augmented reality. This has enabled companies to service machines remotely [7].

Europe 2020, the EU's basic strategy paper, identifies smart and sustainable growth based on knowledge and innovation and a more competitive, environmentally friendly economy with lower material demands as fundamental to the EU's further development. Compared to other major regions in the world, Europe has few companies which produce cutting-edge technologies. Demand for information and communication technologies is also growing in Europe, while only one quarter of the demand is being covered by European 
companies. These basic statements then lead to proposals for the "reindustrialization" of Europe. In this context, it should be noted that a key role in the reindustrialization of Europe will be played by the price of energy, in particular electricity, which forms a part of the process [8].

\section{SWOT ANALYSIS OF INDUSTRY 4.0 AND MATERIAL RESOURCES}

\section{Strengths}

- In the context of Europe, exceptionally high-quality higher education in the area of energy, logistics, smart cities, and chemical and mining technologies.

- High percentage of recycling end-of-life products, the capability of recovering certain types of materials in critical short supply, raw materials.

- $\quad$ Functional, robust energy system.

- $\quad$ Capability of primary processing and extraction of uranium and similar materials.

- Knowledge of nuclear energy processing.

\section{Weaknesses}

- Insufficient ICT infrastructure (data centers, telecommunications environment, slow deployment of smart grid technologies, etc.).

- Low level of knowledge of material flows in economics and components critical to industrial production.

- Insufficient transport infrastructure.

- Insufficient applied research in the field of materials, especially energy sources, and smart cities.

- Improper application of renewable sources in the energy system.

- Insufficient level of investment in modernization of the energy system.

\section{Opportunities}

- Possibility to transform the entire energy, transport and logistics sectors, etc., into more efficient forms.

- $\quad$ Opportunity to participate in the development of standards by supporting innovative pilot projects within transnational consortia.

- $\quad$ Ensuring further sustainable development of the Czech Republic through application of the Industry 4.0 concept and related technologies in the areas of smart cities, intelligent transport, etc.

- $\quad$ Taking advantage of the current interest in smart cities, smart grids and intelligent transport systems and their inclusion in the Industry 4.0 concept.

- Research and production of small-volume technologies for obtaining components/raw materials from already extracted materials ("dumps" and secondary raw materials from end-of-life products).

- Decentralization of the energy system.

Risks

- Difficult communicability of the topic of Industry 4.0 in relation to the efficient use of resources for political representation to the public.

- $\quad$ Lack of interest by energy, transport and other companies to change the overall philosophy of their business, including the implementation of innovative solutions.

- Inconsistent and fragmented component pilot projects which do not lead to expected goals, thereby discrediting the entire concept of Industry 4.0.

- Necessary transformation of the Czech educational system to suit the requirements of the concept Industry 4.0 in the sub-sectors of resource use (energy, transport, security, logistics, etc.) [3]. 


\section{RECOMMENDATIONS}

This chapter summarizes the recommendations obtained based on research in the literature. These recommendations concern how the efficiency of use of material resources in metallurgical processes through Industry 4.0 could be further increased [3]:

- Mapping of material flows in sectors of the national economy and capacities for the acquisition, processing and reuse of critical raw materials.

- Mapping of workplaces needed for the standardization of material efficiency in companies, acquisition and use of raw materials and secondary raw materials.

- $\quad$ Support for the use of big data concepts and advanced data analysis in metallurgy.

- $\quad$ Adoption of a new raw materials strategy and its periodic update in the spirit of the current strategic EU and national initiatives in Industry 4.0.

- Determining the potential for obtaining additional raw materials from today's mined materials.

- Introduction of intelligent components in waste management during the production process, including more environmentally friendly waste disposal.

- $\quad$ Support for research into new mining methods and technological modifications and the respective acquisition/recycling of strategically important materials.

- $\quad$ Student exchange programs at major global research institutes focusing on minerals and secondary resources.

\section{CONCLUSION}

The coronavirus pandemic may accelerate the digital transformation of Czech companies. Businesses have found that investment in digitalization helps them in managing the effects of unexpected crisis. This also applies to companies engaged in metallurgy. The introduction of Industry 4.0 concepts into the operation of smelters is enormously important for resource efficiency, whether it involves, for example, CPS-based control systems, predictive maintenance, recyclability of materials, the ability to obtain additional raw materials from mined materials, or better processing of raw materials as a result of reduced waste.

The Czech Republic has very poor metal resources and other chemical elements and compounds indicated as supercritical by the European Commission. The only strategic fuel and raw material for energy still mined in the Czech Republic (and therefore in the EU) is uranium [9]. Supercritical raw materials are important in metallurgical processes (production of various alloys), and therefore the improved use of input and output components is crucial for the future of metallurgy in the country.

The paper summarized the effects of Industry 4.0 on metallurgical enterprises. It discussed the advantages of improved processing of materials and the production of final products produced with minimum energy consumption, precise input material quantities and minimum waste. This may be reflected in lower selling prices of final products achieved through advanced digitized production lines and machines which are not manually controlled by humans but based remotely on programming technologies.

\section{ACKNOWLEDGEMENTS}

\section{The work was supported by the specific university research of the Ministry of Education, Youth and Sports of the Czech Republic in VSB - Technical University of Ostrava No. SP2021/71.}

\section{REFERENCES}

[1] FRANK, Tomáš. Průmysl 4.0 v kontextu big data. Pilsen, 2017. Thesis. University of West Bohemia. 
[2] Průmys/ 4.0 - automatizačni technika budoucnosti [online]. 2020 [cit. 2021-04-04]. Available from: https://www.engineering.sk/clanky2/automatizacia-robotizacia/2846-prumysl-4-0-automatizacni-technikabudoucnosti.

[3] Ministerstvo průmyslu a obchodu. Iniciativa Průmys/ 4.0 [online]. [citováno 2020-03-18]. Available from: https://www.mpo.cz/cz/rozcestnik/ministerstvo/aplikace-zakona-c-106- 1999-sb/informace-zverejnovane-podleparagrafu-5-odstavec-3-zakona/-iniciativa-prumysl-4-0--230485/.

[4] NOVÁKOVÁ, Alena. Bulletin Průmyslu 4.0 [online]. Národní centrum P 4.0, 2018 [cit. 2021-03-27]. Available from: https://www.ncp40.cz/files/bulletin-prumyslu40-06-2018.pdf

[5] Třinecké železárny: Miliardové investice do automatizace a modernizace výroby [online]. 2017 [cit. 2021-04-04]. Available from: https://www.technickytydenik.cz/rubriky/archiv-technik/trinecke-zelezarny-miliardove-investice-doautomatizace-a-modernizace-vyroby 40548.html

[6] Výhled průmyslu na 2021. Spektrum - časopis svazu průmyslu a dopravy České republiky [online]. 2021, vol. 1 [cit. 2021-04-04]. Available from: https://www.spcr.cz/files/cz/media/spektrum/SP 2021 1Q.pdf

[7] URBANÍK, František. Energie, průmysl a iniciativa Průmysl 4.0. In: Automa [online]. 2018 [cit. 2021-04-04]. Available from: $\underline{\text { https://automa.cz/Aton/FileRepository/pdf articles/9245.pdf }}$

[8] ŠLAJS, Jan. Jak zásadní je pro české hutnictví koncept Průmyslu 4.0. Slévárenství [online]. 2018, vol. 7-8. [cit. 2021-04-04]. Available from: https://issuu.com/inasport/docs/slevarenstvi 7-8 2018

[9] ŠPIČKA, Ivo, TYKVA, Tomáš. PrůmysI 4.0 v Hutním průmyslu. In: Oceláři 33. ročník konference o teorii a praxi výroby a zpracování oceli [online]. 2017, pp. 14-19. [cit. 2021-04-04]. 